\title{
Using Shakespearean drama for creative writing in ESL class room: Some techniques and suggestions
}

\section{IMRANA ISLAM}

In terms of themes and characters as well as of particular speeches, Shakespeare has left a linguistic imprint on the British that is sharper and more memorable than that of any other writer. No one can imagine an English without the famous characters: Hamlet, Romeo, Juliet, Macbeth or Lady Macbeth. Although his language seems peculiar even to contemporary native speakers, it is nothing less than a cultural privilege and obligation to make oneself familiar with at least a selection of Shakespeare. It is believed that culture is part and parcel of language. According to this situation, unless we give ESL students a scope for accessing the cultures of the English speaking world, our tasks will not be fulfilled.

Drama has a great power to draw audiences into an imaginative world where they can enhance their imagination into creativity. We can experience this power no matter where we are, in the comfort of our own house, sitting in a dimly lit theater, or in a language learning class room. By using drama, teachers can provide the arena in which students can become both audience and actor in an imaginative world, enabling students to get incorporated in their imagination and to become less self-conscious about speaking in front of others. Through drama the students can be shifted into other space in which language can be enhanced, challenged and enriched from the outside in, as well as inside out.

Often teachers are put in a position where they become a hindrance to the learning process by prescribing too closely what students should learn. By doing this the teachers fail to create the necessary conditions for learning. In these cases, the student's minimum experience in creative writing and their freedom in imaginative thinking are often disregarded. Their creativity is ignored to the point so that many of them withdraw, and the learning process is adversely affected. Experiences have shown that when students are engaged in highly interactive, affluent-language and enjoyable activities, they become more motivated language learners. In this paper, some techniques have been discussed to give an idea to the 
teachers which they can follow before they prescribe the learning process. The techniques were used in one of my ESL class rooms where the number of students was thirty. The students were from three different Majors, English- 15, Architecture-10 and Environmental Science-5. These students were engaged in highly creative approaches using a wide range of talents to experience new realities. The students who were from non- literature background, at first hesitated to take the challenge of learning language in a non traditional method of reading Shakespearean drama in ESL class, but as they started with the approach, they felt more comfortable in learning the English language than their most familiar old approaches.

\section{Background:}

In the language learning class room, drama can be introduced to any level of language proficiency the students bring to the experience. Drama in role protects the participants from the fear of using language incorrectly. Students can feel comfortable speaking before a group by adapting a new persona and becoming caught up in a group process. Despite its proven effectiveness as a pedagogical tool in Great Britain and more recently in the United States, the teachers of Bangladesh have been somewhat reluctant to adopt drama in educational settings as a teaching strategy in their classrooms. The reasons for this vary but a primary fact may well be lack of familiarity with this approach. Often the teacher misinterprets Drama as putting on a play and may feel uncomfortable with such an undertaking. The truth is that improvisational drama can be very easily put to use with little or no background in drama or theatre. In fact it is also an advantage for those teachers who have no experience on the stage, since their preconceptions of what drama should be, might compel them to turn simple drama activities into theatrical productions.

\section{Literature and transparent language:}

According to Collie and Slater (1987):

Literature can be helpful in the language learning process because of the involvement it fosters in readers . . . The reader is eager to find out what 
happens as events unfold; he or she feels close to certain characters and share their emotional responses. The language becomes transparent; the fiction summons the whole person into its own world . . . It is important to choose books . . . which are relevant to the life experiences, emotions, or dreams of the learner. (p. 2)

By transparent language they seem to be referring to the fact that at one point of involvement in a story, the student is concerned not primarily with grammar and translation, but with the charged and immediate incident or narrative of the story itself. It is important they point out to note that "Literature which speaks to the heart as to the mind, provides material with some emotional color, that can make fuller contract with the learner's own life . . ." (Collie and Slater, 1987, p.2). The dynamic consideration of specific stories, they conclude, might be one of the most prevalent methods of creating a class room environment in which students exist with their ideas and emotions simultaneously.

\section{Provides unanticipated pleasure:}

It is seen that pleasure and interest are keys to engaging non-native speakers in reading Shakespeare. In class rooms it has been noticed that, students lack interest in learning language until they get pleasure from the learning. To create student's interest in learning language through Shakespeare, students were given an activity of rewriting the famous soliloquy, "Tomorrow and tomorrow, and tomorrow . . ." (Act-V, Sc-V, L-19).

In this approach students feel that there can be a sense of play and fun in reading a literary text. It brings about a change in their conception of a language class that they will have to sit silently all term listening to lectures and practicing limited structured exercises.

\section{Increases confidence while reducing anxiety:}

Initially non-native speakers feel uncomfortable to read Shakespeare (Macbeth) in language class. But beginning with rewriting the soliloquy, they quickly come to feel that Shakespeare is something they can undertake. It is also a great advantage 
for the teachers to take Shakespearean dramas to teach language because they can engage the students in any kind of activities that can increase their (students') interest in reading literature to learn language.

I have implemented a few activities in my language class where 30 students participated. After a two weeks session I have noticed a massive change in their responses towards learning language through Macbeth than learning language through other approaches. Many of the students have come requesting me to conduct the whole course using literature. They become more confident in all skills of language (writing, reading, speaking and listening). They feel their own power as learners as they start changing words in the speech. The other key is to reduce students' anxiety and resistance to reading a text that is not in modern English. As they rewrite the soliloquy, they start to identify many words that they already understand and to realize that reading is not going to be a solitary activity done with a dictionary: they and their group partners read and write about it together. Some more activities they can do are to send letters to characters including their opinions, invent new dialogues and create simplified scripts for enacting a scene from the play. No less than British playwright Tom Stoppard has essentially done this exercise and successfully expanded it into a whole play- e.g., Rosencrantz and Guildenstern are Dead. These activities work best when students write in pairs or in small groups. It can be implemented in any class room setting. The teacher only needs to be conscious that the students are comfortable in working in groups or pairs and they are not copying lines from the texts or note books that are available in the market.

The activities are effective for two main reasons:

- They motivate students to learn a non-native language.

- They increase students' confidence level and the students no longer feel insecure of their imaginative power.

In terms of motivation, the writing is purposely student-centered, with students working in pairs or small groups where they can benefit from their peer's insights (Vygotsky, 1978), or as one student characterizes it: “We are doing Macbeth- not just 
reading it." In terms of security writing in groups increases student's confidence level and engaging together in the activities is less intimidating than encountering the play by oneself. The underlying intention is not to cover the entire play, but to engage students in activities that make Macbeth more accessible. In particular, writing enables them to explore their own interpretations and reactions to the experience of reading it. Ultimately, the target of the teachers should be to help students develop a genuine connection between themselves and the text.

\section{Rewriting a speech for creative imagination:}

Rewriting speech encourages students to read closely. As they start rephrasing the famous soliloquy "It is a tale told by an idiot . . ." (Act-V, Sc-V, L-26), replacing some of Shakespeare's words with their own, they have to consider how the original speech is constructed. They notice such factors as how words sound, where they are placed on the page, the number of syllables, the rhythm and intonation of the speech. Furthermore, they start appreciating the beauty of the words of the text; they tamper with the text and understand more clearly what the speech means. Ultimately, when students work directly with the language of Macbeth's speech, it gives them an opportunity to claim something of Shakespeare as their own (Widdowson, 1992). In my creative writing class, I have used a speech from Macbeth, rewriting which the students have gained an access to the language of the seventeenth century in which Shakespeare wrote. A revised speech of "It is a tale told by an idiot . . ." by a group of students of ESL is given in the following example of the proposed activity. Students' examples are given after a little revision in appendix -1 .

\section{Converting a scene into Modern English:}

Writing a scene into modern English is an effective means of getting students to articulate their understanding of character's emotions and motivations. Putting words in the character's mouth lets the students connect themselves with the emotional content of the scene. They may not know what every word in the original scene means, but the words they write for a character to say must be credible in terms of the character's emotional state at a particular point in the plot. Students 
often write what the characters are thinking in parenthesis. Students' examples are given after a little revision in appendix -2 .

\section{Linking themselves to the characters:}

Students can also link themselves to the characters they are reading, by sending letters to the characters expressing their (students') personal opinions about them (characters). This can be another technique that would create an emotional attachment with the characters. This activity is meant to elicit what they are experiencing as first time readers of the speech. By this speech students can get an opportunity to interact with a character, to ask him/ her questions, offer a suggestion, and give the character a piece of their mind. Addressing a character lets students know that Macbeth is not so untouchable, and that there is a place in the course for their own reactions as readers. Reading the letters aloud in class to share with others is often entertaining and can provide a welcome bit of comic relief before proceeding with the rest of the play. Most importantly, by expressing their reactions as not being literature students and tentative interpretations concerning Macbeth, students begin to develop genuine connection to the play. Letters written by students are shown in appendix -3 .

\section{Enhance Creative power as Script Writers:}

In addition with writing a scene in contemporary English, students can invent a new one. This activity permits them to take on the creative role of script writer which they tend to do enthusiastically. Here again, any changes made to the original scene must be credible in terms of reaching the character's emotional state and motivation. In this example the ghost of Banquo appears and directly confronts Macbeth, something he does not do in the original text. Example of an invented scene by a student is given in appendix -4 .

\section{Writing Scripts in Simple Language:}

It is difficult for ESL students to keep an equal sense of emotions of the characters and the movement of the plot when they try to enact a scene from Macbeth. The original speeches are too long for students to remember because of 
the unfamiliar language. In order to facilitate acting out a scene, students create simplified scripts in which some of the words in the longer speeches are removed. This works best with scenes that contain a great deal of action, where it is more apparent which lines of a speech can be deleted. Working with this activity, students can, with great ease, have a direct experience as editors and of speaking the words in the play. In this example students simplify and enact the dramatic bloody scene that describes the catastrophe of the protagonist.

This activity was done in groups. The edited script of one of the groups is given in appendix -5 .

\section{Conclusion:}

Despite the reluctance of the students, it was enjoyable for me to introduce Macbeth_to ESL learners by applying the suggested activities. So I believe, for teachers, using Shakespearean dramas to teach English to non-native speakers will be pleasurable if they follow the suggested activities. ESL students have a remarkable capacity to learn and can do more than the teachers or the students can think possible if they are given the right circumstances. These writings are meant to provide an environment in which the students can have a positive experience with a Shakespearean play in learning English as a Second Language.

\section{Works Cited}

Collie, J. \& Slater, S. (1987). Literature in the language classroom: A resource book of ideas and activities. Cambridge: Cambridge University Press.

Voygotsky, Lev S. (1978). Mind in society. Cambridge MA: Harvard University Press.

Widdowson, Henry. (1992). Practical stylistics. Oxford: Oxford University Press. 


\section{Appendix}

\section{Appendix - 1.}

\section{Original}

Act-V, Sc-V, L-(19-28)

Tomorrow and tomorrow, and tomorrow,

Creeps in this petty pace from day to day,

To the last syllable of recorded time;

And all our yesterdays have lighted fools

The way to dusty death. Out, out, brief candle!

Life's but a walking shadow; a poor player,

That struts and frets his hour upon the stage,

And then is heard no more: It is a tale

Told by an idiot, full of sound and fury,

Signifying nothing.

\section{Student Version}

One day after another moves slowly towards the

Unimportant daily progress, till the last moment is reached and the time till eternity is closed.

And all our past days have simply shown the foolish

Mortals the way to their pale death.

Let the short lived flame of existence be put out!

Life is only a passing illusion, a poor actor

Who performs bravely and worriedly on the stage

And then disappears for ever. Life is like a short story 
as told by a fool; a story full of noise and sentiments

but in the true sense means nothing.

\section{Appendix - 2.}

\section{Original Text:}

Act-I, Sc-VI, L-(58-71)

Macbeth: My dearest love,

Duncan comes here tonight.

Lady Macbeth: And when goes hence?

Macbeth: To-morrow, as he purposes.

Lady Macbeth: O! never

Shall sun that morrow see!

Your face, my thane is as a book, where men

May read strange matters. To beguile the time

Look like the time; bear welcome in your eye,

Your hand, your tongue: He that's coming

Must be provided for, and you shall put

This night's great business into my dispatch;

Which shall to all our nights and days to come

Give solely sovereign sway and masterdom.

Macbeth: We will speak further.

Lady Macbeth: Only look up clear;

To alter favour is to fear.

Leave all the rest to me.

\section{Student Version:}

Macbeth: Dearest love, Duncan is coming tonight. 
Lady Macbeth: When will he depart?

Macbeth: Tomorrow, as he wishes to do.

Lady Macbeth: $\mathrm{O}$ that morning shall never come.

My lord, your face is like an open book

where man can read the strange workings of

your mind. To deceive the world, appear very

normal and simple. You should bear a

welcoming expression on your eye and

face and tongue.

But keep the heinous intentions under it.

Macbeth: We will discuss on the issue later.

Lady Macbeth: Don't look disturbed. Leave everything else to me.

Your appearance may create suspicion.

\section{Appendix - 3.}

Examples of letters written by students to Shakespeare's characters:

\section{Letter to Macbeth:}

$4 / 12 / 2010$

Dear Macbeth,

Basically I think, you are a confused character who believed the prophecies and took horrible decision to murder the king. I am disappointed to see you give in to Lady Macbeth's decision to murder the king. At first you were misguided by the three witches and decided to murder the king. You have suffered from mental conflict many times in the play. But, finally, you murdered him. So, what is the use of thinking? A great warrior, like you, has turned into the most indecisive person. You acted in such a way that you are completely helpless before your wife's decision. A most freaking situation in a man's life. She rebukes you, questions your maturity but you listened to her without any reaction. What 
makes me surprised is by doing so you have defamed yourself in front of me. Your image of a great hero has been lowered to a despicable level of degradation.

In my opinion, you shouldn't have murdered the king who is of your father's age. He awarded you with power, and reward and, most of all, he trusted you more than his own self. Worst of all, you broke the guest-host relationship and thus met your downfall.

\section{Letter to Lady Macbeth:}

January, 3, 2011

Dear Lady Macbeth,

I am surprised to see the cunningness and villainy in you. I can't imagine any woman who wishes to convert her gender only to remove her womanly qualities such as gentleness and kindness. This shows to me how cruel you are! You appear to be a very dutiful and loving wife, but actually you are more cunning and ambitious than Macbeth. I am astonished to see your performance in instigating your husband to murder the king. You did not murder the king with your own hands and kept yourself aloof from being a murderer. On the other hand, you instigated Macbeth to commit the crime. You gave a lame excuse for not undertaking the murder on your own hand. You said that the king looked exactly like your father, so you could not kill him. But why didn't you think this before planning the murder of the king? You also rebuked Macbeth for his abnormal behavior. You have shown much courage, but in the end you lost all your courage. After the murder of the king, you too suffered from mental agony along with Macbeth. Your mental break down due to poignant suffering caused your death. Your final consequence arises my sympathy for you though in the beginning you had created hate in my mind for you and I could not but consider you as a forth witch.

\section{Appendix - 4 .}

\section{Example of student invented scene:}

Ghost: Thanks for recalling me.

Macbeth: What are you doing here? I thought, you were dead?

Ghost: In the new invented scene, the writer wants me to confront you. 
Macbeth: You can not prove, I have murdered you.

Do not shake your blood covered face to scare me.

Ghost: Well, I have come to say you that Fleance is alive.

He will take revenge on his father's death. And the

prophecy of the witches will surely come true.

Therefore, Macbeth you cannot escape your catastrophe.

\section{Appendix - 5.}

\section{Act-V, Sc-I X , L-( 9-34)}

\begin{tabular}{|c|c|}
\hline Original & Students' Script \\
\hline $\begin{array}{l}\text { Macbeth: } \\
\text { Thou losest labour: } \\
\text { As easy may'st thou the interchant air } \\
\text { With thy keen sword impress, as make me bleed: } \\
\text { Let fall thy blade on vulnerable crests, } \\
\text { I bear a charmed life; which must not yield } \\
\text { To one of woman born. }\end{array}$ & $\begin{array}{l}\text { Macbeth: } \\
\text { You are wasting energy in } \\
\text { killing me. My life is secluded } \\
\text { by magic. No man born of } \\
\text { woman can kill me. }\end{array}$ \\
\hline $\begin{array}{l}\text { Macduff: } \\
\text { Despair thy charm; } \\
\text { And let the Angel, whom thou still hast serv'd, } \\
\text { Tell thee, Macduff was from his mother's womb } \\
\text { Untimely ripp'd }\end{array}$ & $\begin{array}{l}\text { Macduff: } \\
\text { Give up your faith and know } \\
\text { the truth that I was a premature } \\
\text { baby and was taken away from } \\
\text { my mother's womb before the } \\
\text { time of maturity. }\end{array}$ \\
\hline $\begin{array}{l}\text { Macbeth: } \\
\text { Accursed be that tongue that tells me so. } \\
\text { For it hath cow'd my better part of man: } \\
\text { And be these juggling fiends no more believed, } \\
\text { That palter with us in a double sense; } \\
\text { That keep the word of promise to our ear, } \\
\text { And break it to our hope.-I'll not fight with thee. }\end{array}$ & $\begin{array}{l}\text { Macbeth: } \\
\text { I curse you for telling the truth. } \\
\text { I am disappointed to know the } \\
\text { truth and have lost my courage } \\
\text { to fight you. }\end{array}$ \\
\hline $\begin{array}{l}\text { Macduff: } \\
\text { Then yield thee coward } \\
\text { And live to be the show and gaze o' th' time: } \\
\text { We'll have thee, so our rearer monsters are, } \\
\text { Painted upon a pole and underwrit, } \\
\text { "Here may you see the tyrant." }\end{array}$ & $\begin{array}{l}\text { Macduff: } \\
\text { Then surrender yourself and get } \\
\text { ready to die. }\end{array}$ \\
\hline Macbeth: & Macbeth: \\
\hline
\end{tabular}




\begin{tabular}{|l|l|}
\hline $\begin{array}{l}\text { I will not yield to kiss the ground before young } \\
\text { Malcom's feet, }\end{array}$ & $\begin{array}{l}\text { I will not surrender to die like a } \\
\text { coward. Even if the prophecies } \\
\text { have come true and I am at the } \\
\text { And to be baited with the rabble's curse. }\end{array}$ \\
$\begin{array}{l}\text { Though Birnam wood be come to Dunsinane, and } \\
\text { thou oppose'd, being of no woman born, yet I will } \\
\text { try the last: }\end{array}$ & $\begin{array}{l}\text { last syllable of my life. Fight } \\
\text { Macduff and meet your death. }\end{array}$ \\
$\begin{array}{l}\text { Before my body I through my warlike shield: lay } \\
\text { ond damn be him that first cries, "Hold, enough". }\end{array}$ & \\
\hline
\end{tabular}

